\title{
Zika Virus Infection and Development of a Murine Model
}

\author{
Ankit Shah $^{1} \cdot$ Anil Kumar ${ }^{1}$
}

Received: 23 May 2016/Revised: 24 May 2016/Accepted: 24 May 2016/Published online: 3 June 2016

(C) Springer Science+Business Media New York 2016

\begin{abstract}
In view of the recent outbreak of Zika virus (ZIKV), there is an urgent need to investigate the pathogenesis of the symptoms associated with ZIKV infection. Since the first identification of the virus in 1947, the pathologies associated with ZIKV infection were thought to be limited with mild illness that presented fever, rashes, muscle aches, and weakness. However, ZIKV infection has been shown to cause Guillain-Barré Syndrome, and numerous cases of congenital microcephaly in children have been reported when pregnant females were exposed to the virus. The severity and the rate of spread of ZIKV in the last year has drawn alarming interest among researchers to investigate murine models to study viral pathogenesis and develop candidate vaccines. A recent study by Lazear and colleagues, in the May 2016 issue of cell host and microbe, is an effort to study the pathogenesis of contemporary and historical virus strains in various mouse models.
\end{abstract}

Keywords ZIKV · Mouse model · Neurodegeneration · IFN- $\alpha / \beta$

Zika virus (ZIKV), a member of flaviviridae family, is a mosquito-borne pathogen, which was originally isolated from a febrile sentinel rhesus monkey in the Zika forest near Entebbe, Uganda (Dick et al. 1952). Apart from ZIKV, the Flavivirus genus also includes the yellow fever virus (YFV), West Nile Virus (WNV), Japanese

Anil Kumar

kumaran@umkc.edu

1 Division of Pharmacology and Toxicology, School of Pharmacy, University of Missouri-Kansas City, 2464 Charlotte Street, Kansas City, MO 64108, USA encephalitis virus (JEV), Chikungunya virus (CHKV), tickborne encephalitis virus (TBEV), and Dengue virus (DENV), many of which are commonly associated with CNS complications (Neal 2014; Sips et al. 2012). The ZIKV genome is $>10 \mathrm{~Kb}$ in length and contains a single open reading frame (ORF) that codes for capsid (C), precursor membrane (PrM), envelope (E), and seven nonstructural proteins formed NS1, NS2A, NS2B, NS3, NS4A, NS4B, and NS5 (Cunha et al. 2016; Ellison et al. 2016; Enfissi et al. 2016; Giovanetti et al. 2016; Ladner et al. 2016; Liu et al. 2016; Nandy et al. 2016). The envelop protein of ZIKV possesses close resemblance to all of the 4 serotypes of dengue virus (DENV), having 54-58\% of homology (Kostyuchenko et al. 2016) and leading to serological cross-reactivity (Lanciotti et al. 2008). In addition, the ZIKV envelop also shares 42, 54, 54, and $40 \%$ homology with YFV, WNV, JEV, and TBEV, respectively (Kostyuchenko et al. 2016).

Since the early isolation of the virus from the monkey, the first human infections were reported in 1952 among patients from Uganda and United Republic of Tanzania (Kindhauser et al. 2016). However, the ZIKV did not receive enough attention until recently when Brazil and other South American Countries reported microcephaly in children born from infected mothers. Although almost 70 years have passed since its first identification, very little is known about the nature and severity associated with ZIKV. Until recent reports, ZIKV infection was estimated to be asymptomatic with almost $80 \%$ of the cases developing mild fever, rashes, arthralgia, and conjunctivitis (Duffy et al. 2009). A few early studies performed in mice reported that ZIKV could replicate and injure the CNS cells, however, no clear evidence was reported to show whether neurodevelopmental defects are associated with ZIKV (Bell et al. 1971; Dick 1952; Way et al. 1976). 
Recent clinical presentations with serious complications indicate that the ZIKV infection is associated with the neurological auto-immune disorder, Guillain-Barré syndrome (GBS), and fetal abnormalities such as microcephaly, placental insufficiency, and cerebral calcification leading to intrauterine growth restriction (Brasil et al. 2016; Oliveira Melo et al. 2016). The growing concerns about the explosive outbreak of ZIKV and lack of antivirals or vaccines prompted the WHO to declare the spread of ZIKV as a Public Health Emergency of International Concern.

In view of the growing threat of autochthonous transmission of ZIKV, several studies have been undertaken to develop a murine model to study ZIKV-associated pathogenesis. Within the last couple of months, several studies have focused on the development of in vivo models to study the ZIKV pathogenesis (Dowall et al. 2016; Lazear et al. 2016; Rossi et al. 2016). The study by Lazear and colleagues used 5 viral strains (MR766, Dakar 41519, Dakar 41667, Dakar 41671, and H/PF/2013) and showed that 4- to 6-week-old mice lacking the IFN receptor and with the ability to produce little IFN $\alpha / \beta$, developed neurological symptoms and succumbed to disease after ZIKV infection with high viral loads in the brain, spinal cord, and testes, which mimic the human ZIKV infection. In contrast to the reports by Dowall and colleagues, which utilized only one strain, the study by Lazear and colleagues provides comprehensive information because they used MR766, Dakar 41519, Dakar 41667, Dakar 41671, and $\mathrm{H} / \mathrm{PF} / 2013$ and compared strains associated with recent outbreaks with the original isolate (MR766). Using a wide range of engineered mice such as Irf3 KO, Irf5 KO, Irf7 KO, Irf3/5/7 triple knockout (TKO), Ifnar ${ }^{-1-}$ (A129), AG129, and CD-1 mice, the study compared the susceptibility to ZIKV in immunocompetent and immunocompromised mice. Unlike previous studies, it used a clinically relevant route of infection (s.c. injections to the footpads and compared the effects with i.p. and i.v. injections). To assess the disease pathology, different read outs such as survival, weight loss, and disease signs (sub-divided into seven categories according to severity of the symptoms) were recorded over 14-30 days. The most severe form of infection was observed in Irf3/5/7 TKO followed by less severity in Ifnar $^{-/-}$mice with significant weight loss within 5 days post-infection. These mice further lost weight over 7 days and died within 10 days post-infection. The fact that TKO mice were more susceptible than Ifnar $^{-1-}$ mice to ZIKV suggests a possible role for IRF-3dependent but IFN- $\alpha / \beta$-independent mechanism. On the other hand, WT mice or Irf3 KO, Irf5 KO, and Irf7 KO mice did not develop clinical symptoms. Similar observations were reported with i.v. injections with higher mortality rates. The susceptibility of ZIKV infection in WT mice was also found to be age dependent since adult WT mice developed no signs of disease, whereas one-third of suckling pups succumbed to infection within 24 days. The A129 mice showed susceptibility to ZIKV infection regardless of age, and mice up to 6 months of age showed morbidity and mortality.

The authors also evaluated the effect of various ZIKV strains and observed more lethality with H/FP/2013 strain as compared to the other strains. Although all the younger mice (4-6 week old) succumbed to the infection, almost $40-80 \%$ of older mice (3-6 month old) survived the ZIKV infection despite showing significant weight loss. In addition, to study the contribution of IFN- $\alpha / \beta$ signaling via the use of knockout mice, the authors also pre-treated mice with anti-IFN- $\alpha \mathrm{R}$ antibodies that resulted in higher viral load in a dose-dependent manner. These results further underlined the role of IFN- $\alpha \mathrm{R}$ in ZIKV pathogenesis. This is an interesting finding because this strategy could be utilized for the development of vaccine in the case of immunocompetent mice by immunizing the WT mice with vaccine followed by challenging with the ZIKV, with and without IFN- $\alpha / \beta$ antibodies. When assessed for viral replication, A129 mice demonstrated high viral loads in spleen, liver, kidney, serum, testes, brain, and spinal cord. The viral loads were 3-4 log cycles higher than initial inoculum $\left(10^{3} \mathrm{FFU}\right)$. The high levels of viremia in the testes demonstrate clinical relevance since sexual transmission is proposed as a possible route of human infection (Dowall et al. 2016). While the model used by Lazear et al. supports the earlier study reporting the presence of ZIKV in the semen (Atkinson et al. 2016), it does not provide any information regarding female reproductive organs, which is a key feature of on-going ZIKV infection leading to neurodevelopmental defects during pregnancy. Further validation of viral distribution in ovaries would consolidate the suitability of the model proposed by Lazear et al. for vertical transmission. Nevertheless, the study clearly provides an important lead toward the development of vaccines that can exploit the IFN- $\alpha / \beta$ signaling pathway.

Considering the urgent need to develop strategies to combat the ZIKV epidemic, studies are rapidly emerging from all over the world in an attempt to develop a suitable model. At the time of writing this report, a study by Cugola et al. (2016) documented vertical transmission from Brazilian strain $\left(\mathrm{ZIKV}^{\mathrm{BR}}\right)$, where they demonstrated infection of pups in SJL mice, resulting in intrauterine growth restriction and microcephaly. The mouse model utilized by Cugala is the closest clinical model of fetal microcephaly at present. In addition to SJL mice, Cugola group also used C57BL/6 mice, which did not show any placental transmission of $\mathrm{ZIKV}^{\mathrm{BR}}$. The observations made in the Lazear study somewhat differs from the Cugola study in that the Lazear study reported severe ZIKV 
infection in 1-week-old C57BL/6 wildtype mice, whereas the older WT mice did not develop clinical disease. Since the Cugola study intended to measure the ZIKV infection only in newborn pups from infected dams and Lazear study only demonstrated disease in newborn pups, it is difficult to judge the suitability of C57BL/6 mouse for vertical transmission. Nevertheless, as pointed out in both the studies, robust anti-viral immune response could be a possible explanation for the resistance observed in C57BL/6 mice. Another study from the Diamond lab (Miner et al. 2016) demonstrated vertical transmission of ZIKV (H/PF/2013 strain) by showing the virus in placenta and fetus from Ifnar-/ - mice in C57BL/6 background. A similar study (Wu et al. 2016) demonstrated vertical transmission of Asian ZIKV (SZ01) in C57 mice. It is likely that the difference between Asian ZIKV (SZ01), ZIKV ${ }^{\mathrm{BR}}$, and Polynesian ZIKV (H/PF/2013) could also play some role and should be considered while choosing the suitability of a mouse model. It is also unclear why some newborn infants may remain unaffected despite ZIKV infection of mothers during pregnancy (Brasil et al. 2016; Schuler-Faccini et al. 2016), which requires further evaluation.

\section{References}

Atkinson B, Hearn P, Afrough B, Lumley S, Carter D, Aarons EJ, Simpson AJ, Brooks TJ, Hewson R (2016) Detection of Zika virus in semen. Emerg Infect Dis 22:940. doi:10.3201/eid2205. 160107

Bell TM, Field EJ, Narang HK (1971) Zika virus infection of the central nervous system of mice. Arch Gesamte Virusforsch 35:183-193

Brasil P, Pereira JP, Raja Gabaglia C Jr, Damasceno L, Wakimoto M, Ribeiro Nogueira RM, de Carvalho Sequeira P, Machado Siqueira A, de Abreu Carvalho LM, da Cotrim Cunha D, Calvet GA, Neves ES, Moreira ME, Rodrigues Baiao AE, de Nassar Carvalho PR, Janzen C, Valderramos SG, Cherry JD, de Bispo Filippis AM, Nielsen-Saines K (2016) Zika virus infection in pregnant women in Rio de Janeiro-preliminary report. N Engl J Med. doi:10.1056/NEJMoa1602412

Cugola FR, Fernandes IR, Russo FB, Freitas BC, Dias JLM, Guimarães KP, Benazzato C, Almeida N, Pignatari GC, Romero S, Polonio CM, Cunha I, Freitas CL, Brandão WN, Rossato C, Andrade DG, Faria DDP, Garcez AT, Buchpigel CA, Braconi CT, Mendes E, Sall AA, Zanotto PMDA, Peron JPS, Muotri AR, Beltrão-Braga PCB (2016) The Brazilian Zika virus strain causes birth defects in experimental models. Nature. doi:10.1038/ nature 18296

Cunha MS, Esposito DL, Rocco IM, Maeda AY, Vasami FG, Nogueira JS, de Souza RP, Suzuki A, Addas-Carvalho M, Barjas-Castro Mde L, Resende MR, Stucchi RS, Boin Ide F, Katz G, Angerami RN, da Fonseca BA (2016) First complete genome sequence of Zika virus (Flaviviridae, Flavivirus) from an Autochthonous transmission in Brazil. Genome Announc 4:e00032. doi:10.1128/genomeA.00032-16

Dick GW (1952) Zika virus. II. Pathogenicity and physical properties. Trans R Soc Trop Med Hyg 46:521-534
Dick GW, Kitchen SF, Haddow AJ (1952) Zika virus. I. Isolations and serological specificity. Trans $\mathrm{R}$ Soc Trop Med Hyg 46:509-520

Dowall SD, Graham VA, Rayner E, Atkinson B, Hall G, Watson RJ, Bosworth A, Bonney LC, Kitchen S, Hewson R (2016) A susceptible mouse model for Zika virus infection. PLoS Negl Trop Dis 10:e004658. doi:10.1371/journal.pntd.0004658

Duffy MR, Chen TH, Hancock WT, Powers AM, Kool JL, Lanciotti RS, Pretrick M, Marfel M, Holzbauer S, Dubray C, Guillaumot L, Griggs A, Bel M, Lambert AJ, Laven J, Kosoy O, Panella A, Biggerstaff BJ, Fischer M, Hayes EB (2009) Zika virus outbreak on Yap Island, Federated States of Micronesia. N Engl J Med 360:2536-2543. doi:10.1056/NEJMoa0805715

Ellison DW, Ladner JT, Buathong R, Alera MT, Wiley MR, Hermann L, Rutvisuttinunt W, Klungthong C, Chinnawirotpisan P, Manasatienkij W, Melendrez MC, Maljkovic Berry I, Thaisomboonsuk B, Ong-Ajchaowlerd P, Kaneechit W, Velasco JM, TacAn IA, Villa D, Lago CB, Roque VG, Jr, Plipat T, Nisalak A, Srikiatkhachorn A, Fernandez S, Yoon IK, Haddow AD, Palacios GF, Jarman RG, Macareo LR (2016) Complete genome sequences of Zika virus strains isolated from the blood of patients in Thailand in 2014 and the Philippines in 2012. Genome Announc 4:e0359. doi:10.1128/genomeA.00359-16

Enfissi A, Codrington J, Roosblad J, Kazanji M, Rousset D (2016) Zika virus genome from the Americas. Am Lancet 387:227-228. doi:10.1016/S0140-6736(16)00003-9

Giovanetti M, Faria NR, Nunes MR, de Vasconcelos JM, Lourenco J, Rodrigues SG, Vianez JL Jr, da Silva SP, Lemos PS, Tavares FN, Martin DP, do Rosario MS, Siqueira IC, Ciccozzi M, Pybus OG, de Oliveira T, Alcantara LCJ (2016) Zika virus complete genome from Salvador Bahia, Brazil. Infect Genet Evol 41:142-145. doi:10.1016/j.meegid.2016.03.030

Kindhauser MK, Allen T, Frank V, Santhana RS, Dye C (2016) Zika: the origin and spread of a mosquito-borne virus. Bull World Health Organ. doi:10.2471/BLT.16.171082

Kostyuchenko VA, Lim EX, Zhang S, Fibriansah G, Ng TS, Ooi JS, Shi J, Lok SM (2016) Structure of the thermally stable Zika virus. Nature. doi:10.1038/nature17994

Ladner JT, Wiley MR, Prieto K, Yasuda CY, Nagle E, Kasper MR, Reyes D, Vasilakis N, Heang V, Weaver SC, Haddow A, Tesh RB, Sovann L, Palacios G (2016) Complete genome sequences of Five Zika virus isolates. Genome Announc 4:e00377. doi:10. 1128/genomeA.00377-16

Lanciotti RS, Kosoy OL, Laven JJ, Velez JO, Lambert AJ, Johnson AJ, Stanfield SM, Duffy MR (2008) Genetic and serologic properties of Zika virus associated with an epidemic, Yap State, Micronesia, 2007. Emerg Infect Dis 14:1232-1239. doi:10.3201/ eid1408.080287

Lazear HM, Govero J, Smith AM, Platt DJ, Fernandez E, Miner JJ, Diamond MS (2016) A mouse model of Zika virus pathogenesis. Cell Host Microbe 19:720-730. doi:10.1016/j.chom.2016.03.010

Liu L, Wu W, Zhao X, Xiong Y, Zhang S, Liu X, Qu J, Li J, Nei K, Liang M, Shu Y, Hu G, Ma X, Li D (2016) Complete genome sequence of Zika virus from the first imported case in Mainland China. Genome Announc 4:e00291. doi:10.1128/genomeA. 00291-16

Miner JJ, Cao B, Govero J, Amber SA, Fernandez E, Cabrera OH, Garber C, Noll M, Klein RS, Noguchi KK, Mysorekar KK, Diamond IU, Michael S (2016) Zika virus infection during pregnancy in mice causes placental damage and fetal demise. Cell 165:1-11. doi:10.1016/j.cell.2016.05.008

Nandy A, Dey S, Basak SC, Bielinska-Waz D, Waz P (2016) Characterizing the Zika virus genome-A bioinformatics study, Curr Comput Aided Drug Des,

Neal JW (2014) Flaviviruses are neurotropic, but how do they invade the CNS? J Infect 69:203-215. doi:10.1016/j.jinf.2014.05.010 
Oliveira Melo AS, Malinger G, Ximenes R, Szejnfeld PO, Alves Sampaio S, Bispo de Filippis AM (2016) Zika virus intrauterine infection causes fetal brain abnormality and microcephaly: tip of the iceberg? Ultrasound Obstet Gynecol 47:6-7. doi:10.1002/ uog. 15831

Rossi SL, Tesh RB, Azar SR, Muruato AE, Hanley KA, Auguste AJ, Langsjoen RM, Paessler S, Vasilakis N, Weaver SC (2016) Characterization of a Novel Murine Model to Study Zika Virus. Am J Trop Med Hyg. doi:10.4269/ajtmh.16-0111

Schuler-Faccini L, Ribeiro EM, Feitosa IM, Horovitz DD, Cavalcanti DP, Pessoa A, Doriqui MJ, Neri JI, Neto JM, Wanderley HY, Cernach M, El-Husny AS, Pone MV, Serao CL, Sanseverino
MT, Force BMGSZET (2016) Possible association between Zika virus infection and microcephaly-Brazil, 2015. Morb Mortal Week Rep 65:59-62. doi:10.15585/mmwr.mm6503e2

Sips GJ, Wilschut J, Smit JM (2012) Neuroinvasive flavivirus infections. Rev Med Virol 22:69-87. doi:10.1002/rmv.712

Way JH, Bowen ET, Platt GS (1976) Comparative studies of some African arboviruses in cell culture and in mice. J Gen Virol 30:123-130. doi:10.1099/0022-1317-30-1-123

Wu KY, Zuo GL, Li XF, Ye Q, Deng YQ, Huang XY, Cao WC, Qin CF, Luo ZG (2016) Vertical transmission of Zika virus targeting the radial glial cells affects cortex development of offspring mice. Cell Res. doi:10.1038/cr.2016.58 